\title{
Suppressive Effects of Calcium Polysulfide on Filamentous Bulking in Activated Sludge Process
}

\author{
TOHRU IYO', TSUNEO YOSHINO', and SHIGERU OHNO ${ }^{2}$ \\ ${ }^{1}$ Environmental Industrial Health Course, School of Allied Health Sciences, Kitasato University \\ /15-1, Kitasato 1-Chome, Sagamihara-City, Kanagawa 228, Japan \\ ${ }^{2}$ School of Hygienic Sciences, Kitasato University \\ /15-1, Kitasato 1-Chome, Sagamihara-City, Kanagawa 228, Japan
}

\begin{abstract}
We investigated the suppressive effects on filamentous bulking by the addition of calcium polysulfide (CPS). Laboratory experiments were conducted on three activated sludge systems with various loadings of CPS. The influent CPS in the three systems were 0,100 , and $200 \mathrm{mg} \cdot \Gamma^{1}$. All systems were operated under the same conditions, that is $0.24 \mathrm{~kg} \cdot \mathrm{m}^{-3} \cdot$ day $^{-1}$ of TOC volumetric loading rate, 24 hours of hydraulic retention time, temperature at $25{ }^{\circ} \mathrm{C}$, and were approximately operated at the same sludge loadings. A mixture of glucose and pepton was used as the substrate and easily caused the filamentous bulking. The mixed cultures developed in the systems mentioned possessed average SVI values of 400, 232, and 129 $\mathrm{m} l \cdot \mathrm{g}^{-1}$ respectively. From microscopic and microbial observation, the high SVI value was caused by a high content of filamentous microorganisms in the developed mixed cultures. The series with CPS had different microflora compared with the control series with no loading of CPS. It was concluded that CPS suppressed the growth of filamentous microorganisms, and led to the growth of non-filamentous ones, i.e., Zooglea-like flocs.
\end{abstract}

Key words : filamentous bulking, calcium polysulfide; settling characteristics; microflora of activated sludge

\section{INTRODUCTION}

Activated sludge processes are widely used because of their high performance and flexibility in coping with various situations. However it has been recognized that bulking of activated sludge is a serious problem of process operating. Bulking of activated sludge can be caused by many factors, and one frequent cause is the excessive growth of filamentous micro$\operatorname{organisms}^{1)-8)}$ in a mixed culture, i.e., Sphaerotilus natans, Type 021N, Type 1701, Haliscomenobacter hydrossis, Microthrix parvicella,
Thiothrix, Beggiatoa, and Nocardia. A high content of filamentous microorganisms in activated sludge usually results in a high value of sludge volume index (SVI). There are a number of previous articles ${ }^{9)-20)}$ on the mechanisms and process control of bulking in the activated sludge process. Although various kinds of new information regarding filamentous bulking has been accumulated, it is usually difficult to predict the occurrence of bulking in activated sludge. Consequently, we consider that chemical agents acting on filamentous microorganisms have a great practical value. Bactericides such as 
hydrogen peroxide, chlorine and other chemicals are often used as a bulking suppressant ${ }^{21)-24)}$. Furthermore, positive effects of calcium ion on microbial coagulation and high density are reported by Tezuka ${ }^{25)}$, Kakii et $a l^{26)}$, and Iyo et $a l^{27)}$. From these viewpoints, calcium polysulfide (CPS), one bactericide for gardening, might be used as the bulking suppressant because it is a bactericide containing calcium. To investigate the suppressive effects of CPS on filamentous bulking, the activated sludge process to which CPS was added in an aeration tank was studied in our laboratory. Effects, such as the settling characteristics, the microscopic analyses and the microfloras in activated sludge are discussed in the experimental results.

\section{MATERIALS AND METHODS}

Materials CPS was used, which was produced by Hokuko Chemical Industry Co. Ltd. Tokyo, Japan. Activated sludge was obtained from the aeration tank of a conventional activated sludge plant in Kitasato University Hospital, Kanagawa, Japan. Table 1 shows the composition of the synthetic wastewater which was used. It consisted of glucose and pepton as the original organic compounds, producing with ease the filamentous bulking. The synthetic wastewater was sterilized by autoclaving at 121 ${ }^{\circ} \mathrm{C}$ for 20 minutes.

Operational Conditions Three different experimental conditions according to the loading of CPS were created. Although Run 1 was the control series with no loading of CPS, RUNs 2 and 3 were loaded with CPS. The other experimental conditions were held constant; $2000 \mathrm{mg} \cdot \Gamma^{1}$ of seeded activated sludge in concentration, $0.24 \mathrm{~kg} \cdot \mathrm{m}^{-3} \cdot \mathrm{day}^{-1}$ of TOC volumetric loading rate, 24 hours of hydraulic retention time (HRT), and a temperature of 25 ${ }^{\circ} \mathrm{C}$ (Table 2).

Apparatus Three series of experimental apparatus for cultivating activated sludge were used. Fig. 1 shows that our bench scale continuous culture tank consisted of an aeration

Table 1 Composition of the synthetic wastewater

\begin{tabular}{lrl}
\hline \multicolumn{1}{c}{ Components } & \multicolumn{1}{c}{ Quantity } \\
\hline Glucose & 14,000 & $\mathrm{mg} \cdot l^{-1}$ \\
Pepton & 14,000 & $\mathrm{mg} \cdot l^{-1}$ \\
$\mathrm{KH}_{2} \mathrm{PO}_{4}$ & 2,500 & $\mathrm{mg} \cdot l^{-1}$ \\
$\mathrm{MgSO}_{4} \cdot 7 \mathrm{H}_{2} \mathrm{O}$ & 15,000 & $\mathrm{mg} \cdot l^{-1}$ \\
$\mathrm{NaCl}$ & 10,000 & $\mathrm{mg} \cdot l^{-1}$ \\
$\left(\mathrm{NH}_{4}\right)_{2} \mathrm{SO}_{2}$ & 7,000 & $\mathrm{mg} \cdot l^{-1}$ \\
$\mathrm{NaHCO}_{3}$ & 15,000 & $\mathrm{mg} \cdot l^{-1}$ \\
$\mathrm{TOC}$ & 12,000 & $\mathrm{mg} \cdot l^{-1}$ \\
$\mathrm{~T}-\mathrm{N}$ & 3,600 & $\mathrm{mg} \cdot l^{-1}$ \\
$\mathrm{~T}-\mathrm{P}$ & 600 & $\mathrm{mg} \cdot l^{-1}$ \\
\hline
\end{tabular}

Table 2 Operational conditions

\begin{tabular}{lcccc}
\hline & $\begin{array}{c}\text { CPS } \\
\left(\mathrm{mg} \cdot l^{-1}\right)\end{array}$ & $\begin{array}{c}\text { TOC loading rate } \\
\left(\mathrm{kg} \cdot \mathrm{m}^{-3} \cdot \mathrm{day}^{-1}\right)\end{array}$ & $\begin{array}{c}\text { HRT } \\
(\mathrm{hr})\end{array}$ & $\begin{array}{c}\text { Temp. } \\
\left({ }^{\circ} \mathrm{C}\right)\end{array}$ \\
\hline RUN 1 & 0 & 0.24 & 24 & 25 \\
RUN 2 & 100 & 0.24 & 24 & 25 \\
RUN 3 & 200 & 0.24 & 24 & 25 \\
\hline
\end{tabular}




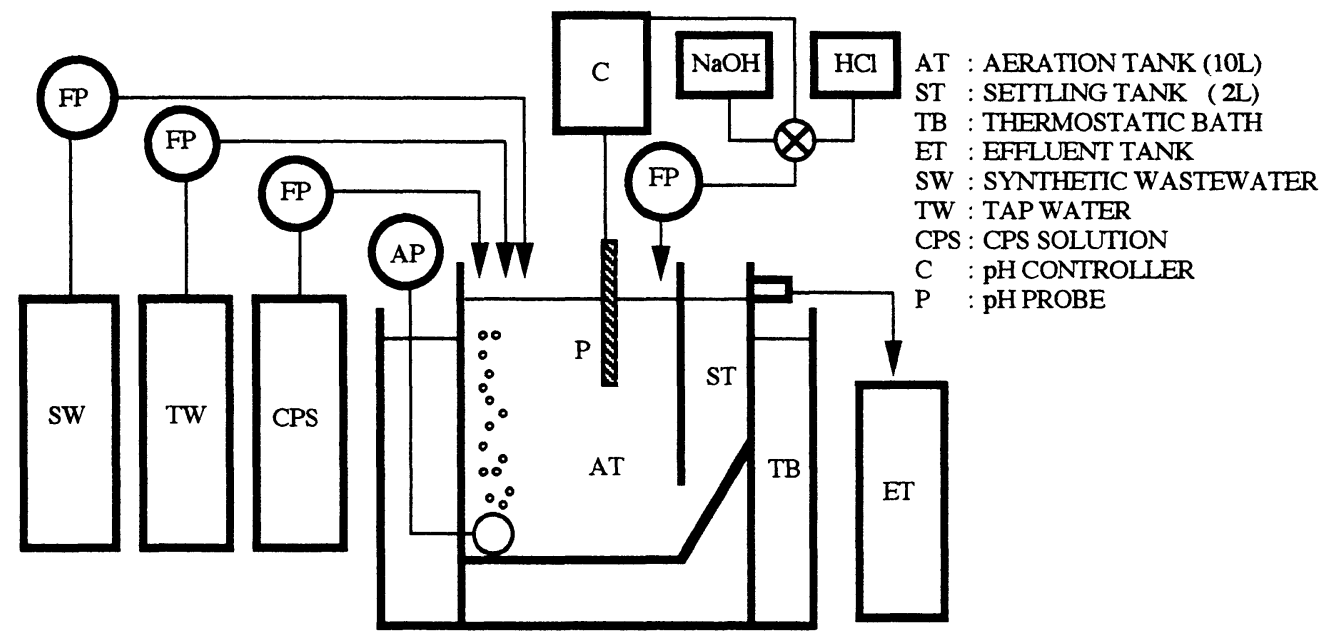

Fig. 1 Schematic diagram of experiment appratus.

tank $(10 l)$ and a settling tank $(2 l)$. The temperature in the apparatus was controlled by the use of a thermostatic bath. Synthetic wastewater, tap water, and CPS solution were separately supplied to the aeration tank with three micro tube pumps under the fixed conditions as shown in Table 2. The aeration flow rate was approximately controlled to 3 $\mathrm{L} \cdot \mathrm{min}^{-1}$. It was adequate for both mixing the activated sludge and supplying air to the activated sludge in the aeration tank. The $\mathrm{pH}$ in the aeration tank was also controlled to around neutrality by use of an automatic $\mathrm{pH}$ controller. Hydrochloric acid and sodium hydroxide were the chemical reagents used as controlling the pH.

Analytical methods We carried out a series of analyses using Standard Methods for the Examination of Wastewater ${ }^{28)}$ published by the Japan Sewage Works Association. Settled sludge volume (SV), mixed liquor suspended solids (MLSS), mixed liquor volatile suspended solids (MLVSS), sludge volume index (SVI), and zone setting velocity (ZSV) were measured to obtain the settling characteristics of activated sludge. The process water quality was estimated by TOC. TOC was determined on a Shimadzu model 500 TOC analyzer.

Light and electron microscopic examination The activated sludge in the developed mixed culture was observed by phase-contrast microscopy with an Olympus microscope at regular intervals. Filamentous microorganisms for scanning electron microscopy (SEM) were fixed in a $0.1 \mathrm{M}$ phosphate buffer ( $\mathrm{pH} 7.2$ ) containing $2 \%$ gulutaraldehytde and then in a $1 \% \mathrm{OsO}_{4}$ solution, and dehydrated through a graded series of water-ethanol mixtures. The ethanol was gradually replaced by a nonpolar solvent isoamyl acetate. The samples were dried by the critical point drying method and subsequently sputter-coated with platinum-palladium. SEM observations were made on a AKASHI ISI-DS 130S scanning electron microscope.

Microbial observation For the isolation of microorganisms in the activated sludge, the following procedures ${ }^{29)}$ were used. The deflocculation of the activated sludge was used with an ultrasonic dispersal method for 2.5 minutes on ice using an ultrasonic generator at $150 \mathrm{~W}$. Subsequently, the activated sludge was diluted gradually and the diluted series were plated onto a CGY medium (Bact-casitone $5 \mathrm{~g}$, glycerol $5 \mathrm{~g}$, Bact-yeast extract 1g, Bact-agar $14 \mathrm{~g}$, 

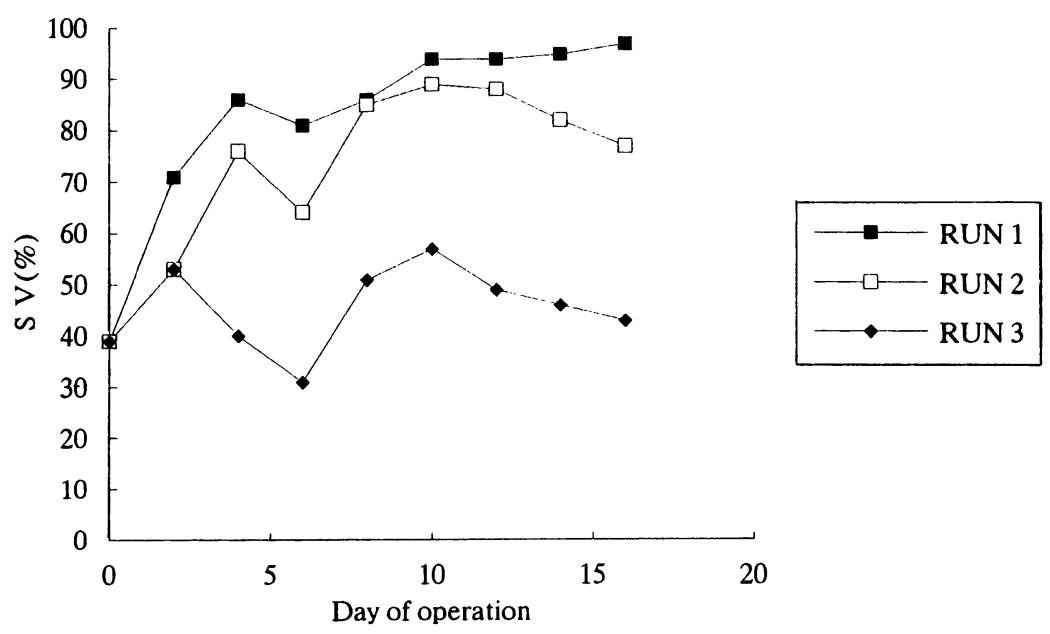

Fig. 2 Changes of SV.

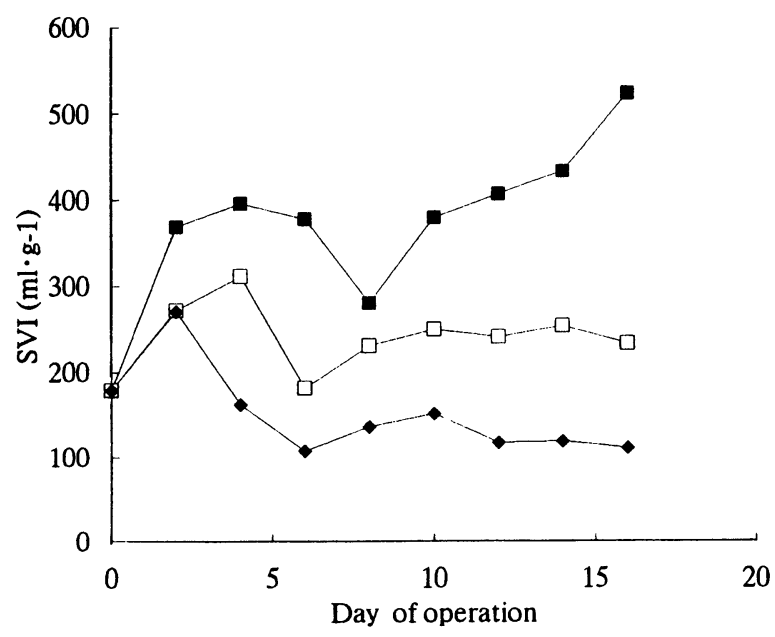

Fig. 3 Changes of SVI.

distilled water $1000 \mathrm{ml}, \mathrm{pH} 7.2$, after sterilization by autoclaving at $121{ }^{\circ} \mathrm{C}$ for 20 minutes). The plates were incubated at $22{ }^{\circ} \mathrm{C}$ for 10 to 14 days. Bacterial colonies on the plate were individually inoculated by CGY broth (Bact-casitone $5 \mathrm{~g}$, glycerol $5 \mathrm{~g}$, Bact-yeast extract $1 \mathrm{~g}$, distilled water $1000 \mathrm{ml}, \mathrm{pH} 7.2$, after sterilization by autoclaving at $121{ }^{\circ} \mathrm{C}$ for 15 minutes), and the broths were incubated at $22{ }^{\circ} \mathrm{C}$ for 7 days. At the end of the isolation, each of the broths containing homogeneous microorganisms were plated onto a CGY plate to obtain the isolated colonies. The identification of microorganisms isolated from the activated sludge was determined by a test of Gram staining, Shape, Acid fast, Spores, Motility, Catalase, Oxidase, and Oxidation-Fermentation. According to "Cowan and Steel's Manual for the Identification of Medical Bacteria ${ }^{\text {m0) }}$, the genera of microorganisms separated was estimated.

\section{RESULTS}

Settling Characteristics of activated sludge Figs. 2, 3, and 4 show the changes in SV, SVI, and ZSV, respectively. RUN 1, the control series with 


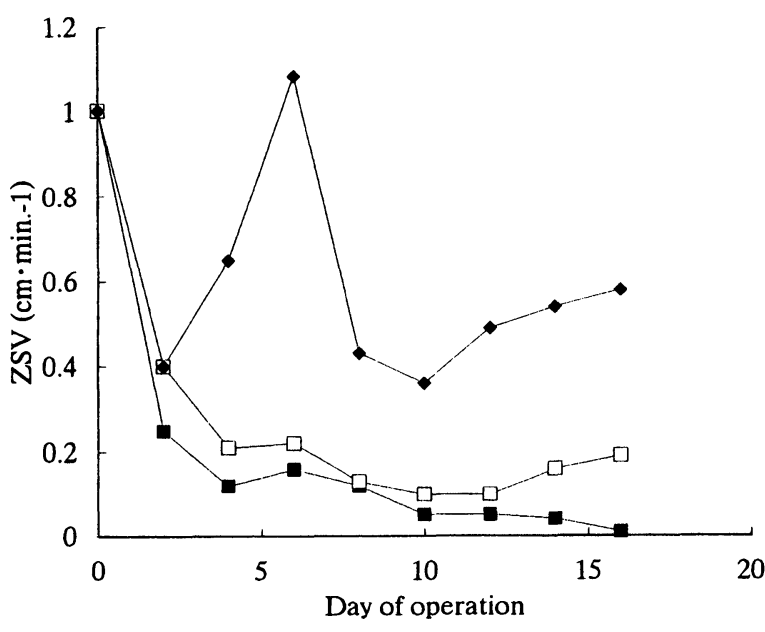

Fig. 4 Changes of ZSV.

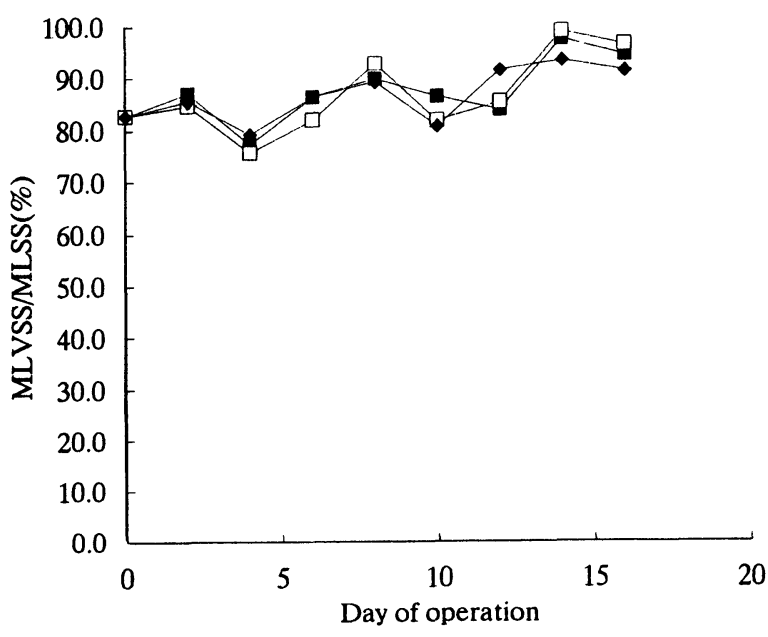

Fig. 5 Changes of MLVSS/MLSS ratio.

no loading of CPS, showed the complete filamentous bulking state, i.e., $90 \%$ of SV, 400 $\mathrm{m} l \cdot \mathrm{g}^{-1}$ of SVI, and $0.08 \mathrm{~cm} \cdot \mathrm{min}^{-1}$ of $\mathrm{ZSV}$ on the average after 4 days. RUN 2 with $100 \mathrm{~m} l \cdot \mathrm{g}^{-1}$ of CPS loading showed the suppressive effect on the filamentous bulking because it had lower SV and SVI, and higher ZSV than Run 1, i.e., $81 \%$ of $\mathrm{SV}, 232 \mathrm{~m} l \cdot \mathrm{g}^{-1}$ of SVI, and $0.16 \mathrm{~cm} \cdot \mathrm{min}^{-1}$ of ZSV on the average after 6 days. RUN 3 with 200 $\mathrm{m} l \cdot \mathrm{g}^{-1}$ of CPS loading also showed the suppressive effect on filamentous bulking because it had the lowest SV, SVI, and ZSV, i.e., $45 \%$ of SV, 129 $\mathrm{m} l \cdot \mathrm{g}^{-1} \mathrm{SVI}$, and $0.6 \mathrm{~cm} \cdot \mathrm{min}^{-1}$ of $\mathrm{ZSV}$ on the average after 4 days. Because all the experimental series showed the same tendency, i.e., more than $80 \%$ of MLVSS/MLSS ratios and a slight increase in MLVSS/MLSS ratios, the low SVI and the high ZSV in the CPS loaded series refers not to physical effects but to bacterial flora (Fig. 5). It was suggested that CPS, one kind of bactericide, could be utilized for suppressing the filamentous bulking in the activated sludge process.

Treatment Efficiency RUNs 2 and 3 with CPS loadings showed high TOC treatment efficiency during the whole period. In both 


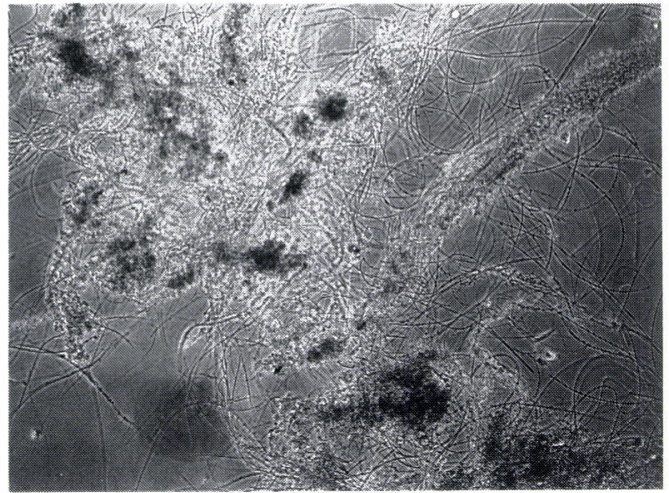

(a) Light microscopic photograph (x 100) [RUN 1]

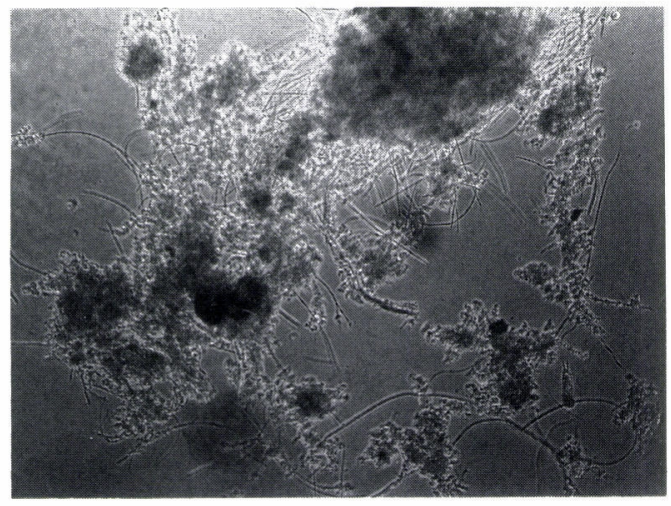

(c) Light microscopic photograph (x 100) [RUN 2]

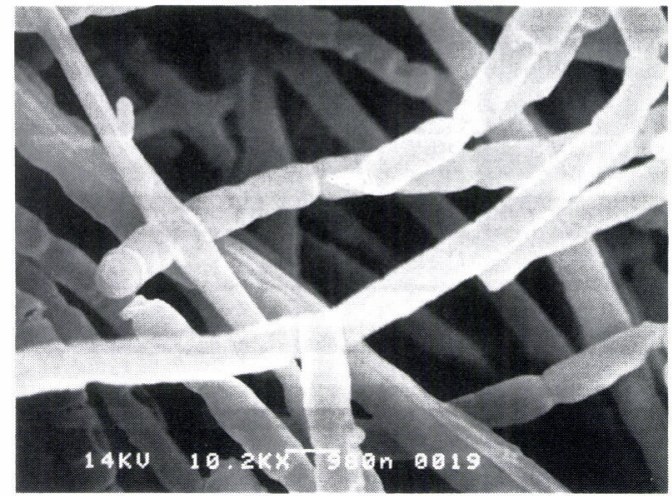

(b) SEM photograph (x 10000) [RUN 1]

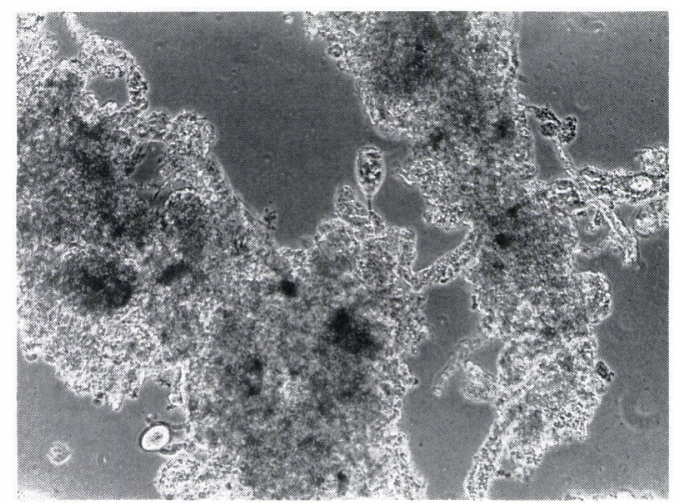

(d) Light microscopic photograph (x 200) [RUN 3]

Fig. 6 Photographs of activated sludge.

series, the TOC removal rate was maintained at more than $90 \%$ on average. From the data, it was concluded that CPS did not affect the treatment efficiency under these conditions.

Microflora in activated sludge Because of the high contents of filamentous microorganisms in activated sludge (Fig. 6a), RUN 1 showed complete filamentous bulking. From SEM observation as show in Fig. 6 b, the cells of the filamentous microorganisms of RUN 1 were enclosed within a rigid sheath and appeared to be round-ended rods. The cell size had a width of approximately $1 \mu \mathrm{m}$ and a length of approximately $2 \mu \mathrm{m}$. The filamentous microorganisms formed slightly bent filaments often with false branching. From these morphological characteristics, we estimate that the filamentous microorganisms belonged to Sphaerotlius natans or Type 1701. The activated sludge of RUN 2 had few filamentous microorganisms and many Zooglea-like flocs. The length of the filamentous microorganisms of RUN 2 were shorter than that of RUN 1 (Fig. 6c). Fig. 6d shows that the dominant microorganisms in the activated sludge of RUN 3 were mostly Zooglea-like microorganisms rather than filamentous microorganisms. In both CPS loaded series, Vorticella sp. and Arcella sp. of Protozoa, Colurella $s p$., Lecane sp., and Lepadella sp. of Metazoa were often observed. The Protozoa and Metazoa 


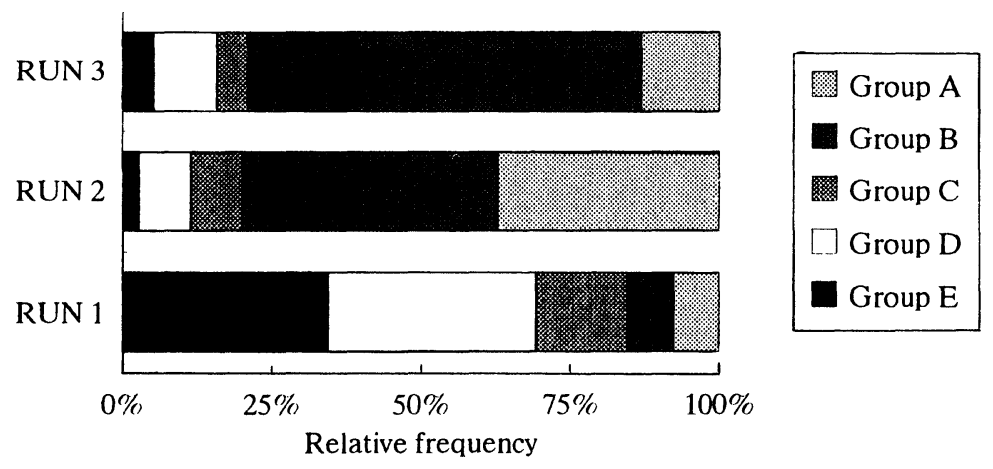

Group A : Gram negative, rod-shaped, Catalase negative, Oxidase negative Group B : Gram negative, rod-shaped, Catalase negative, Oxidase positive Group C : Gram positive, spherical

Group D : Gram negative, rod-shaped, Catalase positive, Oxidase negative Group E: Gram negative, rod-shaped, Catalase positive, Oxidase positive

Fig. 7 Microflora in activated sludge.

are observed when activated sludge shows good treatment characteristics. The data in Figs. $6 c$ and $6 \mathrm{~d}$ suggest the suppressive effects of CPS on filamentous bulking in activated sludge.

Gram negative, rod-shaped bacteria were dominant in all series of activated sludge. The Oxidation-Fermentation (OF) test was ambiguous because the bacteria isolated from activated sludge did not grow well on the $\mathrm{OF}$ media. In this study, the microflora of the activated sludge was divided into five separate groups; Group A : Gram negative, rod-shaped, Catalase negative, Oxidase negative, Group B : Gram negative, rod-shaped, Catalase negative, Oxidase positive, Group C : Gram positive, spherical, Group D: Gram negative, rod-shaped, Catalase positive, Oxidase negative, Group E : Gram negative, rod-shaped, Catalase positive, Oxidase positive. Fig. 7 shows that the microflora between the CPS loaded series (RUNs 2 and 3) and the control series (RUN 1) was different. The majority of the bacteria in RUNs 2 and 3 were Gram negative, rod-shaped, Catalase negative, and Oxidase negative strains (Group A) and Gram negative, rod-shaped, Catalase negative, and Oxidase positive strains (Group B). This data suggests that the predominant bacteria in RUNs 2 and 3 belonged to the genera Streptobacillus (Group A), Cardiobacterium (Group B), and Haemophilus (Group A or B). On the other hand, the majority of bacteria in RUN 1 were Gram negative, rod-shaped, Catalase positive, and Oxidase negative strains (Group D), and Gram negative, rod-shaped, Catalase positive, and Oxidase positive strains (Group E). The data suggests that the predominant bacteria of RUN 1 belonged to the genera Acinetobacter, Enterobacteriaceas (Group D), Alcaligenes, Flavobacterium, Pseudomonas, Acinetobacillus, Aeromonas (Group E), etc. From this data and the microscopic observations (Fig. 6), the filamentous microorganisms, considered as Sphaerotlius natans or Type 1701, belonged to Group D or E, i.e., Gram negative, rod-shaped, Catalase positive, and Oxidase negative or positive strains.

\section{DISCUSSION}

Bulking may be caused by many types of filamentous microorganisms ${ }^{1)}$. When we developed the activated sludge with no loading of CPS in our experiment, the strain type of the filamentous microorganisms obtained would be 
Sphaerotlius natans or Type 1701 because the filamentous microorganisms had a rigid sheath, round-ended rod-shaped cell, and false branching. This conclusion is supported by the finding that the filamentous microorganisms isolated were Gram negative, Oxidase positive, and Catalase positive. Kohno ${ }^{31)}$ describes how Sphaerotlius natans is Gram negative, Catalase positive, and Oxidase positive, and Williams and $\mathrm{Unz}^{32)}$ have shown that Type 1701 may be related to the genus Sphaerotilus. Because the classification of filamentous microorganisms has been mainly based on morphology, there have been some previous reports on the Catalase and Oxidase reactions. Recent researchers ${ }^{8), 33)}$ have showed, however, that Sphaerotlius natans was Gram negative, Catalase negative, and Oxidase positive. The results of this study, i.e. the quantity of filamentous microorganisms was proportional to the relative frequency of Catalase and Oxidase positive strains, suggest that the genus Sphaerotlius natans and Type 1701 would be a Gram negative, Catalase positive, and Oxidase positive group.

Sphaerotlius natans and Type 1701 are the most commonly observed filamentous microorganisms in bulking sludges in the USA ${ }^{34)}$. Sphaerotlius natans and Type 1701 successfully compete with a floc former at low DO concentrations because they have a lower half-saturation coefficient for DO than a representative floc former ${ }^{10)}$. Filamentous bulking occurred even in the aeration tank of RUN 1 on high DO concentrations during the experiment. We conclude from this data that the suppressive effects of CPS on filamentous bulking were not attributable to the high DO condition.

CPS reacts with oxygen and carbohydrate in water, and produces active sulfur, calcium thiosulfate, calcium sulfate, calcium carbonate, and hydrogen sulfide. The chemical reactions of CPS are as follows.

$$
\begin{aligned}
& \mathrm{CaS}_{5}+2 \mathrm{O}_{2} \longrightarrow \mathrm{CaSO}_{4}+4 \mathrm{~S} \\
& 2 \mathrm{CaS}_{5}+3 \mathrm{O}_{2} \longrightarrow 2 \mathrm{CaS}_{2} \mathrm{O}_{3}+6 \mathrm{~S}
\end{aligned}
$$

$$
\begin{aligned}
& \mathrm{CaS}_{2} \mathrm{O}_{3}+\mathrm{O} \longrightarrow \mathrm{CaSO}_{4} \\
& \mathrm{CaS}_{5}+\mathrm{CO}_{2}+\mathrm{H}_{2} \mathrm{O} \longrightarrow \mathrm{CaCO}_{3}+\mathrm{H}_{2} \mathrm{~S}+4 \mathrm{~S}
\end{aligned}
$$

The bactericidal activity of CPS is mainly attributed to the active sulfur because it can be easily permeable into the cell membrane of microorganisms. Chlorine, a bactericide as is CPS, was used to control activated sludge bulking in the 1930s. The technique was popularized by Jenkins $e t a l^{23)}$. The effects of chlorine on filamentous bulking are influenced by the species of filamentous microorganisms, the dosing point in the activated sludge process, and the dose of chlorine ${ }^{34)}$. The effective dose of chlorine on various microorganisms containing filamentous microorganisms varies over a range of more than three orders of magnitude ${ }^{24)}$. Because CPS is a bactericide as is chlorine, further studies on the filamentous species, the dosing point, and the effective dose would be required to establish a practical technique.

The active site of calcium on the sludge settleability could not be clarified in the present study. Kakii et $a l^{26)}$ describe, however, that calcium ions play an important role not only in the flocculation of activated sludge but also in determining sludge characteristics such as SV. They also found $\mathrm{Ca}$ ions dependent on floc forming bacterium ${ }^{35)}$. Tezuka ${ }^{25)}$ describes that a Flavobacterium species predominant in activated sludge showed the calcium-dependent flocculation. This data shows the positive effects of calcium on sludge settleability. On the other hand, $\mathrm{Webb}^{36)}$ shows that the negative effects of calcium on sludge settleability, i.e., Haliscomenobacter hydrossis which is a bacterium frequently encountered in bulking sludge, is dependent on calcium ions for growth.

Pike et al. ${ }^{37)}$ describe that the majority of bacteria in activated sludge are Gram negative rods belonging to the genera Pseudomonas, Achromobacter, and Flavobacterium-Cytophaga. These bacteria did not become dominant bacteria in the activated sludge of RUNs 2 and 3 , while the activated sludge in the CPS loaded 
series showed both good settleability and good treatment characteristics.

\section{CONCLUSIONS}

The results of this study suggest that CPS suppressed the filamentous bulking that was caused by Sphaerotlius natans or Type 1701, and was effective for the growth of Zooglea-like flocs in activated sludge. The activated sludge in the CPS loaded series showed good settleability and good treatment characteristics. It is suggested that the predominant bacteria in the CPS loaded series belonged to the genera Streptobacillus, Cardiobacterium, and Haemophilus (Group A or B).

\section{ACKNOWLEDGMENT}

The authors thank Associate Professor Tetsuro Kohno (Department of Civil and Environmental Engineering, Yamanashi University, JAPAN) for useful suggestions on the identification of the filamentous microorganisms and Professor Yutaka Futaesaku (School of Hygienic Sciences, Kitasato University, JAPAN) for his help and advice in the scanning electron microscopy.

\section{REFERENCES}

1) Eikelboom D. H. : Filamentous organisms observed in activated sludge, Wat. Res., 9, 365-388 (1975).

2) Matsui S. and Yamamoto R. : Roles of filamentous microbes to affect compression and reflocculation processes of activated sludges, Jour. Japan Sewage Works Assoc. 21 (236), 46-55 (1984) (in Japanese)

3 ) Strom P. F. and Jenkins D. : Identification and significance of filamentous microorganisms in activated sludge, Jour. WPCF, 45, 829-836 (1984)

4) Williams T. M. : The nutrition of Thiothrix, Type 021N, Beggiatoa and Leucothrix strains, Wat. Res., 23, 15-22 (1989)

5 ) Yasuda M., Yasuda I. : Identification of filamentous microorganisms and factors in- fluencing on them in activated sludge, Japan Jour. Wat. Pollut. Res., 9, 87-96 (1986) (in Japanese)

6 ) Kohno T.: Morphology, physiology, and nutrition of a sulphur-oxidizing filamentous organism isolated from activated sludge, Wat. Sci. Tech., 20, 241-247 (1988)

7 ) Slijkhuis H. and Deinema M. H. : Effect of environmental conditions on the occurrence of Microthrix parvicella in activated sludge, Wat. Res., 22, 825-828 (1988)

8 ) Ziegler M., Lange M. and Dott W. : Isolation and morphological and cytological characterization of filamentous bacteria from bulking sludge, Wat. Res., 24, 1473-1451 (1990)

9 ) Chudoba J., Ottova V. and Madera V. : Control of activated sludge filamentous bulking -1 . Effect of the hydraulic regime or degree of mixing in an aeration tank, Wat. Res., 7, 1163-1182 (1973)

10) Hao O. J., Rechard M. G. and Jenkins D. : The half-saturation coefficient for dissolved oxygen : A dynamic method for its determination and its effect on dual species competition, Biotechnol. Bioeng. 25, 403-416 (1983)

11) Lau A. O., Strom P. F. and Jenkins D. : Growth kinetics of Sphaerotilus natans and a floc former in pure and dual continuous culture, Jour. WPCF, 56, 41-51 (1984)

12) Van Niekerk A. M., Jenkins D. and Richard M. G. : The competitive growth of Zooglea ramigera and Type $021 N$ in activated sludge and pure culture - A model for low F : M bulking, Jour. WPCF, 59, 262-273 (1987)

13) Wanner J., Kucman K. and Grau P. : Activated sludge process combined with biofilm cultivation, Wat. Res., 22, 207-215 (1988)

14) Yasuda M. : Effect of anoxic / anaerobic condition on filamentous bulking in activated sludge process, Japan Jour. Wat. Pollut. Res., 10, 351-358 (1987) (in Japanese)

15) Yamamoto R. and Matui S. : Influence of contact loading on polysaccharide storage and settleability of activated sludge, Wat. Sci. Tech., 21, 16392-1642 (1989)

16) Brenner D. and Argaman Y. : Control of sludge settling characteristics in the single-sludge system. a hypothesis, Wat. Res., 24, 1051-1054 (1990)

17) Inamori Y., Kuniyasu Y., Sudo R. and Koga M. : Control of the growth of filamentous microorganisms using predacious ciliated protozoa, Wat. Sci. Tech., 23, 2493-2496 (1991) 
18) Rensink J. H. and Donker H. J. G. W. : The effect of contact tank operation on bulking sludge and biosorption processes, Wat. Sci. Tech., 23, 857-866 (1991)

19) Echeverria E. Seco A. and Ferrer J. : Control of activated sludge settleability using preparation and precipitation, Wat. Res., 27, 293-296 (1993)

20) Pujol R. and Canler J. P. : Biosorption and dynamics of bacterial populations in activated sludge, Wat. Res., 26, 209-212 (1993)

21) Cole C. A., Stamberg J. B. and Bishop D. F. : Hydrogen peroxide cures filamentous growth in activated sludge, Jour. WPCF, 45, 829-836 (1973)

22) Akiyama N., Hamanishi T. and Hasegawa T. : Improvement of poor sedimentation in activated sludge by using an ionene polymer, Jour. Water and Waste, 33, 825-833 (1991) (in Japanese)

23) Jenkins D., Neethling J. B., Bode H. and Richard M. J. : The use of chlorination for control of activated sludge bulking. In Bulking of Activated sludge : Preventive and Remedial Methods (Edited by Chambers B. and Tomlinson E. J.), 187-206. Horwood, Chichester (1982)

24) Neethling J. B., Jenkins D. and Johnson K. M. : Chemistry, microbiology, and modeling of chlorination for activated sludge bulking control, Jour. WPCF, 57, 882-889 (1985)

25) Tezuka Y. : Cation-dependent flocculation in a Flaavobacterium species predominant in activated sludge, Appl. Microbiol., 17, 222-226 (1969)

26) Kakii K., Kitamura S. Shirakashi T. and Kuriyama M. : Effect of calcium ion on sludge characteristics, J. Ferment. Technol., 63, 263-275 (1985)
27) Iyo T., Yoshino T. and Ohno S. : Suppressive effects on filamentous bulking by addition of corn cob flour and divalent metal ions, Wat. Sci. Tech., 26, 2493-2496 (1992)

28) Japan Sewage Works Association : Standard Methods for the Examination of Wastewater (1984) (in Japanese)

29) Hashimoto S., Fujita M. and Ike M. : Studies on enumeration methods for activated sludge bacteria, Jour. Japan Sewage Works Assoc., 26 (298), 45-48 (1989) (in Japanese)

30) Cowan S. T. : Cowan and Steel's Manual for the Identification of Medical Bacteria, Cambridge University Press (1974)

31) Kohno T. : Personal communication (1994)

32) Williams T. M. and Unz R. F. : Isolation and characterization of filamentous bacteria present in bulking activated sludge, Appl. Microbiol,. Biotechnol., 22, 273-282 (1985)

33) Richard M., Hao O and Jenkins D. : Growth kinetics of Sphaerotilus species and their significance in activated sludge bulking, Jour. WPCF, 57, 68-81 (1985)

34) Jenkins D., Richard M. G. and Neethling J. B. : Causes and control of activated-sludge bulking, Wat. Pollut. Control, 84, 455-454 (1984)

35) Kakii K., Sugahara E. and Shirakashi T. : Isolation and characterization of $\mathrm{Ca}^{2}+$ -dependent floc-forming bacterium, J. Ferment. Technol., 64, 57-62 (1986)

36) Webb L. E.: Calcium dependence of the filamentous bacterium Haliscomenobacter hydrossis, Wat. Res., 22, 1317-1320 (1988)

37) Pike E.B. and Carrington E. G. : Recent developments in the study of bacteria in the activated sludge process, Wat. Pollut. Control, 72, 583-605 (1972)

(Submitted 1994. 5.10)

(Accepted 1994. 5.25) 